\title{
Organizational Excellence: Approaches, Models and Their Use at Czech Organizations
}

\author{
DOI: 10.12776/QIP.V22I2.1129
}

Jaroslav Nenadál, David Vykydal, David Waloszek

Received: 29 May 2018

Accepted: 02 June 2018

Published: 31 July 2018

\begin{abstract}
Purpose: The paper brings a set of original information related to analysis and description of the current state in the area of excellence models implementation in Czech organisations. It defines these terms, analyses results of special research in Czech organisations and proposes a comprehensive and generic framework how to achieve the organisational excellence. The principal goal of this paper is to present the main possibilities, benefits, limitations and risks related to the practical use of excellence models in Czech organisations.
\end{abstract}

Methodology/Approach: Brainstorming conferences, field research and relevant data analysis, seminars with quality professionals and other managers, comparative literature analysis and interviews were used to reach the principal goal.

Findings: The organisational excellence concept is now widely discussed and implemented throughout the world. Unlike, the real situation in most Czech organizations is rather else. Level of knowledge and overall people awareness related to this concept and various excellence models is very low. This finding supports the assumption that is necessary to change company culture towards never-ending excellence effort in Czech organisations by way of systematic knowledge (including best practices) sharing among all levels of organizations staff.

Research Limitation/implication: Special research activities focused on analysis and description of current state in area of excellence models implementation, which was performed on a sample of 321 Czech organisations (with more than $20 \%$ response rate). Such level of response rate was seriously influenced by the fact that practical use of various excellence models in Czech organisations is rather limited in present days. However, we can suppose the obtained results should be valid or interesting also for another organization, not only in the Czech Republic. 
Originality/Value of paper: The paper brings an original set of information from special market research as well as the development of a creative and generic framework of the organisational excellence tailored to Czech organisations.

Category: Research paper

Keywords: organizational excellence; excellence models; quality; risks; benefits

\section{INTRODUCTION}

Organizations in today's ever-changing and global business environment need to focus on creating new approaches to their development. Such approaches should provide confidence in the organisation's ability to achieve long-term and sustained success. So-called "organisation excellence" represents one of the most recognised concepts which can assure such ability. The organisational excellence ensures all organisational systems are aligned and functioning cohesively together.

We can find a lot of opinions and definitions related to the organisation excellence. For example, M. Webster says that "organisational excellence is delivering, and sustaining the delivery of, outstanding value to all key stakeholders" (Webster, 2016). Experts from American Society for Quality argue that "organisational excellence refers to ongoing efforts to establish an internal framework of standards and processes intended to engage and motivate employees to deliver products and services that fulfil customer requirements within business expectations" (ASQ, 2015). D. M. Bailey wrote: "The excellence is a cultural journey" (Bailey, 2014). Moreover, according to European Foundation for Quality Management - EFQM: "Excellent organisations are those that achieve and sustain outstanding levels of performance that meet or exceed the expectations of all their stakeholders" (EFQM, 2012). These four statements create only very small sample of opinions focused on the area of the organisational excellence concept but anyway they prove the organisational excellence has been being an actual phenomenon throughout the world!

On the contrary, we are afraid of fact the journey to excellence is the only exception and rare opportunity for most of the Czech companies now. A lot of Czech organisations are strongly oriented only to quality management systems according to ISO 9001 standard, and various excellence models are looked upon vain instruments. Therefore, it seems to be rational to explore the reasons and consequences of this situation. The primary purpose of this paper is to present interesting findings from special field research in the area of the organisational excellence concept implementation as well as to bring original excellence framework tailored for Czech organisations environment and culture. 


\section{METHODOLOGY}

After necessary literature review and mutual comparison of five known excellence models, the authors used a questionnaire field survey as the instrument to collect data from 321 Czech organisations. Production, as well as service organisations, were included into this sample on the basis of randomly drew. A quantitative and qualitative approach were used in the data processing. The EFQM Excellence Model was used as an example of a time-tested approach to reaching the organisational excellence. Findings enabled to create original excellence framework as basic of Czech journey to excellence.

\section{LITERATURE REVIEW}

When consulting serious literature resources in the area of the organisational excellence or excellence models, we can discover huge amount of various opinions and experience. Let us remind only some of them.

Experts from the International City/County Management Association (ICMA) for example recommend focusing on eight areas in case organisations strive to achieve organisational excellence:

1) Delight your customers.

2) Get results from vision and strategic planning.

3) Create a culture from your values.

4) Understand and incorporate both leadership and management.

5) Pay attention to engagement and passion.

6) Maximizing performance.

7) Measure progress.

8) Manage changes.

See (ICMA, 2016) for additional details. Some findings from field research projects revealed a significant impact of organizational excellence on overall performance (Musa and Tulay, 2008) or (Kiitam and Tammaru, 2012), human force productivity (Shirvani and Iranban, 2013), company culture creating (AlDhaafri, Al-Swidi and Al-Ansi, 2016; Zgodavova, Hudec and Palfy, 2017) and other features of organizations. A lot of other interesting perceptions and beliefs are continuously presented through permanent chatting on www.researchgate.com. Some special approaches were developed on purpose of organisational excellence level assessment. Let us remind only three of them: the RADAR logic as EFQM (2012) developed a dynamic assessment framework and Duffy (2016) have proposed five excellence maturity levels and similar approach is also recommended by the latest version of ISO 9004:2018 standard, which comprises a special annex entirely oriented on organizational self-assessment (ISO 9004; 2018). By the way: this standard brings a new term "quality of an 
organisation" as the degree to which the inherent characteristics of an organisation fulfil the needs and expectations of its customers and other interested parties, to achieve sustained success. In our opinion, this term is broadly speaking close to the organisational excellence.

Unfortunately, data relating to the economic impact of the organisational excellence are presented only seldom. For example, results of a particular survey oriented to change of performance indicators show as interesting itself. This survey was executed in 2007 by some specialists from George Washington University (Washington D.C.) They are summed up in Tab. 1.

Table 1 - Effects of Organisational Excellence (Adapted from GWU, 2017)

\begin{tabular}{|l|c|}
\hline \multicolumn{1}{|c|}{ Performance Indicator } & $\begin{array}{c}\text { Average Annual Positive Performance } \\
\text { Improvement (\%) }\end{array}$ \\
\hline Timeliness of delivery & 4.7 \\
\hline Errors or defects & 10.3 \\
\hline Cost of quality & 9.0 \\
\hline Employee satisfaction & 1.4 \\
\hline Safety and Health & 1.8 \\
\hline Overall customer satisfaction & 2.5 \\
\hline Customer complaints & 11.6 \\
\hline Market share & 13.7 \\
\hline Sales per employee & 8.6 \\
\hline Return on assets & 1.3 \\
\hline
\end{tabular}

However, such data cannot be confirmed by similar research in Czech organisations at all. Impact of organisational excellence to overall performance was discovered by another research, conducted by a team from the University of Leicester at 120 European organisations. The European Quality Award winners were compared against organisations, where the EFQM Excellence Model was not introduced yet. Detailed results are available at (Eraclitus, 2005). According to our investigation, up to now, the broadest qualitative research focused on the real impacts of the organisational excellence was provided by Asian Productivity Organization. Strengths, as well as weaknesses, were precisely identified in five areas:

- impact of business excellence,

- design of business excellence frameworks,

- awareness of business excellence,

- application of business excellence, 
- business excellence awards (see Mann (2011) for more details).

Journey to the organisational excellence can also bring some serious risks or obstacles; there is no doubt about it. P. Hoskote (2015) nicely identified 12 essential reasons for possible failing, including misunderstanding and misuse tools, no benchmarking activities, no accountability, etc.

In the course of time, various excellence models have crystallised as a fundamental and critical instrument for promoting and practical implementation of all excellence principles. Such models have already discussed and developed in more than 90 countries throughout the world. Ladzani (2016) has made some interesting comparisons of different versions of excellence models. According to our investigations, it is possible to distinguish two different groups of these models:

a) Models which are launched and presented by institutions and serves not only as guidelines but also as a set of criteria for national or international quality awards. Only three of them were selected for the next investigation:

- Deming Prize Model (JUSE, 2017),

- Malcolm Baldrige National Quality Award Model (ASQ, 2017),

- EFQM Excellence Model (EFQM, 2012).

Currently, these models are widely known and respected.

b) Models which were developed and are promoted by individuals, wellknown experts. These models usually serve as a tool of organisational inspiration and support. As examples of such models can be introduced:

- Kanji's Business Excellence Structural Model (Kanji, 2015),

- 4P and 3C Model (Oakland, 2014).

We have studied and mutually compared these models. Essential features are described in Tab. 2.

Table 2 - Basic Features of Selected Excellence Models

\begin{tabular}{|l|l|}
\hline \multicolumn{1}{|c|}{ Excellence Model } & \multicolumn{1}{c|}{ Basic Features } \\
\hline $\begin{array}{l}\text { Deming Prize Model } \\
\text { (JUSE, 2017) }\end{array}$ & $-\begin{array}{l}\text { It represents probably the oldest model throughout the } \\
\text { world. It has been continuously developing and using } \\
\text { since 1951. }\end{array}$ \\
& $-\begin{array}{l}\text { It accents broad application of the statistical approach to } \\
\text { data processing. }\end{array}$ \\
- & $\begin{array}{l}\text { Established criteria are a little bit unspecific. } \\
\text { This model is mostly applied in countries in South-East } \\
\text { Asia. }\end{array}$ \\
\hline $\begin{array}{l}\text { Malcolm Baldrige National } \\
\text { Quality Award Model }\end{array}$ & $-\begin{array}{l}\text { It was created in 1987 with the strong support of the US } \\
\text { government. }\end{array}$ \\
\hline
\end{tabular}




\begin{tabular}{|c|c|}
\hline Excellence Model & Basic Features \\
\hline (ASQ, 2017) & $\begin{array}{l}\text { - Criteria were gradually developed for different areas } \\
\text { (business, education, healthcare, etc.) and they are } \\
\text { permanently refined. } \\
\text { - } \\
\text { This model is highly respected especially in North } \\
\text { America, but its implementation could also be } \\
\text { discovered in other continents. }\end{array}$ \\
\hline $\begin{array}{l}\text { EFQM Excellence Model } \\
\text { (EFQM, 2012) }\end{array}$ & $\begin{array}{l}\text { - The first version of this model was launched in } 1991 \text { as } \\
\text { the European Model of TQM. } \\
\text { - Its criteria are fully generic, and it is recognized as the } \\
\text { most exacting excellence model at present. } \\
\text { - All criteria are divided into two parts: enablers, as well } \\
\text { as results. } \\
\text { - It is widely used particularly in European countries and } \\
\text { also serves as the fundament of many national quality } \\
\text { awards. }\end{array}$ \\
\hline $\begin{array}{l}\text { Kanji’s Business Excellence } \\
\text { Structural Model } \\
\text { (Kanji, 2015) }\end{array}$ & $\begin{array}{l}\text { - Kanji has already launched the first version of his model } \\
\text { in } 1998 . \\
\text { - } \quad \text { The leadership role is appreciated as a key one. } \\
\text { - } \quad \text { It is a set of reasonably intangible recommendations. } \\
\text { - This model is known and applied to different } \\
\text { organisations in Europe and Asia. }\end{array}$ \\
\hline $\begin{array}{l}\text { 4P and 3C Model } \\
\text { (Oakland, 2014) }\end{array}$ & $\begin{array}{l}\text { - Primarily, soft items of management are stressed by this } \\
\text { model. } \\
\text { - The leadership role is strongly oriented to the overall } \\
\text { development of company culture. } \\
\text { - Practical implementation of this model asks for the } \\
\text { manager's creativity. }\end{array}$ \\
\hline
\end{tabular}

In practice, many discussions may be held about mutual relationship or differences between the ISO 9000 family of standards concept and organisational excellence concept. Fonseca published some findings in this area (Fonseca, 2015). Our investigation proved his findings, additionally; we can stress three crucial differences:

a) All excellence models (as instruments aimed at achieving the organisational excellence) have dynamic nature. They are upgraded and refined continuously. Unlike, especially ISO 9001 standard is looked upon rather static set of requirements - revision intervals are much longer in comparison to excellence models' development.

b) While ISO 9001 standard aims to product's quality, all excellence models face quality of an organization. Only ISO 9004 standard (mentioned above) is related with the organisational quality.

c) Most of the excellence models recognise ISO 9001 standard as one of the suitable tools, no more, no less. 
Finally, we can say the excellent organisations can be distinguished through the following features:

- they highly exceed „mere average“ of performance within the relevant branch of business,

- their leaders can reach organisational identity with the support of the clear vision, mission and values through,

- they understand that adding the highest stakeholders' value is their primary reason for being,

- they are strongly oriented to all stakeholders' requirements, not only external customers,

- they see that excellent results are reached as a logic effect of advanced and continuously developed management systems,

- they are distinguished through the highest level of overall company culture,

- soft items of management are usually preferred to hard methods and tools there,

- instead ,ex-post““ actions, a prevention principle is in place everywhere,

- systematic manner exploits all suitable approaches to organisation's learning,

- they are strongly oriented to products and processes innovations and people creativity,

- they systematically stipulate, manage and improve critical processes,

- they are aware of their role in the sustained development of the regional and national economy,

- corporate social responsibility is fundamental basis of a relationship with the community.

\section{RESULTS OF EMPIRICAL FIELD RESEARCH}

We performed empirical field research in Czech organisations from November 2017 till February 2018. A principal goal of this research was to investigate how the excellence models are practically perceived, used and assessed by Czech managers from the point of effects and risks.

For this purpose, we declared three primary hypotheses:

$H_{1}$ : $\quad$ Excellence models are applied only seldom at Czech organisations.

$\mathrm{H}_{2}$ : $\quad$ Time and various resources demands represent the most critical barriers to organisational excellence establishing. 
$H_{3}$ : Reaching the excellence as a whole helps to organisations' performance improvement.

321 Czech organisations from various areas of business were randomly selected. Data gathering was based on a structured questionnaire which could be filled mostly by electronic aid. Additionally, interviews with some quality professionals were also held. A response rate was $19 \%$ what means that 61 organisations gave us relevant data for next processing. Tab. 3 shows the organisation's distribution from the business area point of view.

Table 3 - Organization's Distribution from the Business Area Point of View

\begin{tabular}{|l|c|}
\hline Business area & Percentage \\
\hline Automotive industry & 24.72 \\
\hline Machinery & 23.60 \\
\hline Healthcare & 8.99 \\
\hline Electronic industry & 5.62 \\
\hline Food industry & 5.62 \\
\hline Chemical industry & 4.49 \\
\hline Education & 4.49 \\
\hline Metallurgy & 3.37 \\
\hline Public service & 3.37 \\
\hline Other & 15.73 \\
\hline
\end{tabular}

$22.95 \%$ from this sample were large organisations (it means with more than 500 employees), 57.37 employed from 50 to 500 people and 19.67 of respondents were representatives from small organisations. Only 5.93\% of all organisations had not established and certified quality management system minimally against relevant management systems standard (ISO 9001, IATF 16949, ISO/TS 16949, ISO 14001 or so).

There are some interesting findings:

a) Only about $16 \%$ of Czech organisations work with some excellence models. Majority of Czech organisations (about 84\%) still strongly depend on some of the standards, as ISO 9001 or IATF 16949 only! On the contrary, more than $64 \%$ of Czech organisations included declared their awareness of excellence models although this awareness shallow very often.

Causes of insufficient awareness are plotted in Fig. 1. Nearly $46 \%$ of organisations look at the most important problems lack of resources and information and lack of top managers concern. Insufficient knowledge of 
employees also seems to be grave reason related to insufficient awareness about excellence models.

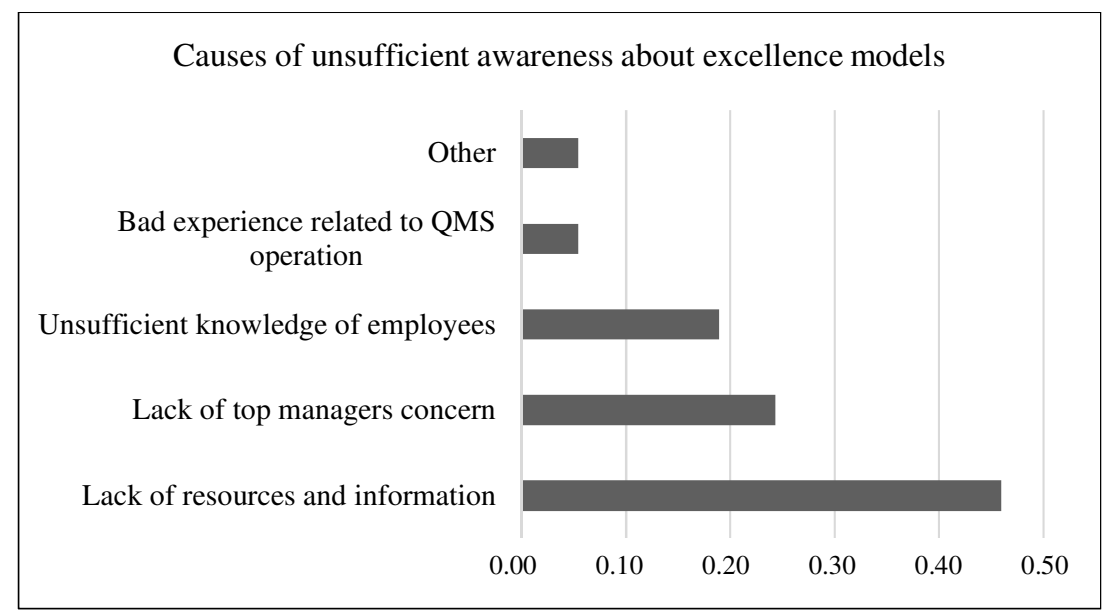

Figure 1 - The Leading Causes of Insufficient Awareness about Excellence Models in Czech Organisations (QMS - Quality

Management System)

The fact that only $16 \%$ of Czech organisations work with some excellence model despite $64 \%$ of them have specific awareness about such models is an apparent discrepancy. It should be explained by the reluctance of many Czech companies to be interested in the area of the organisational excellence (briefly: none of the management standards' requirement asks for such effort!). Additionally: about $75 \%$ of organisations included in research have no intention to implement some excellence model in the future!

b) Top managers' strategic decisions need for next quality management development and overall organisation's performance increasing were the most frequent impulses for some excellence model implementation.

c) On the contrary, some severe barriers to successful implementation of excellence models were discovered through our field research (Fig. 2) for their description. The total lack of employees is an unpleasant reality in every Czech company due to rapid decreasing of unemployment level. However, a little bit surprising is a high percentage of top managers' mistrust and a declaration that advanced quality management system is not a priority for them. Such mental obstacles should be difficult to overcome! 


\section{Barriers of excellence models implementation}

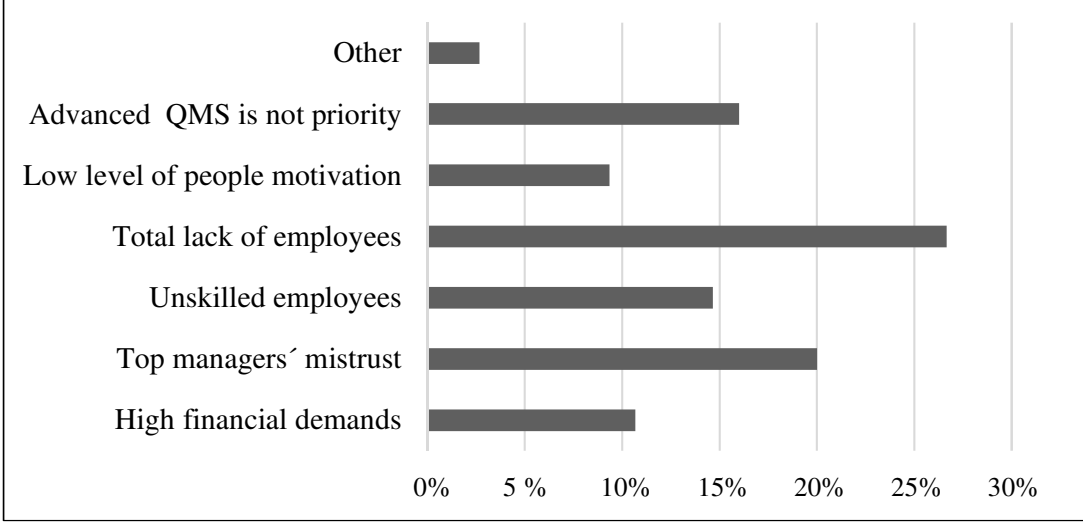

Figure 2 - The Main Barriers to Excellence Models' Implementation in Czech Organisations

More than $86 \%$ of Czech organisations are a hundred per cent sure that effort in the area of the organisational excellence will bring them serious performance increasing. Fig.3 draws it.

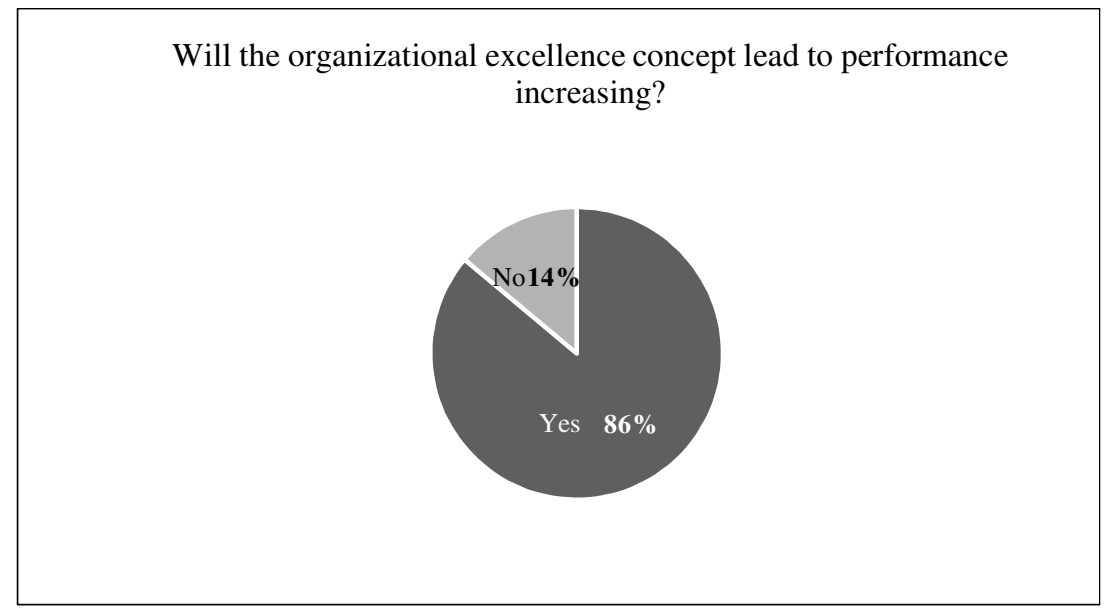

Figure 3 - Impact of Organisational Excellence Concept to Performance Increases in Czech Organisations

d) When exploring the main benefits of excellence models' implementation, Czech managers primarily stressed quality improvement of the management system. Also, some other positive effects were described. They are briefly presented in Fig. 4 and are mostly linked to the area of certain stakeholders' perception. 


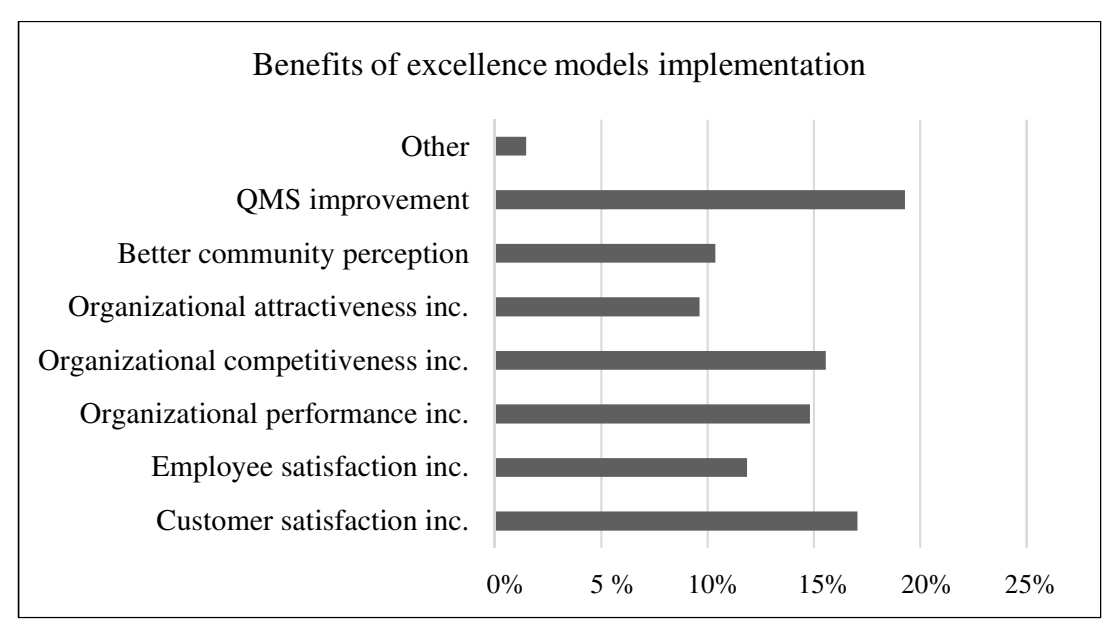

Figure 4 - Estimated Benefits of Excellence Models' Implementation in Czech Organisations (Inc. - Increasing)

e) A final question of our research targeted to main areas of improvement. Surprisingly, only about $11.5 \%$ of Czech organisations consider profit is increasing as the most crucial area. On the other hand, overall cost reduction is preferred by nearly $19 \%$ of organisations. Moreover, about $16 \%$ of respondents declared customer perception as the most important challenge. See Figure 5 for more details. Practically, all experience throughout the world confirmed that excellence models assure such kinds of improvement from a long-term perspective. Moreover, it can be recognised as another argument for systematic establishing of excellence models at Czech organisations!

As a whole, findings from our investigations convincingly confirmed all three hypotheses! However, they also revealed that most of the Czech managers and other groups of people have entirely insufficient knowledge in the field of excellence models' development and implementation. 


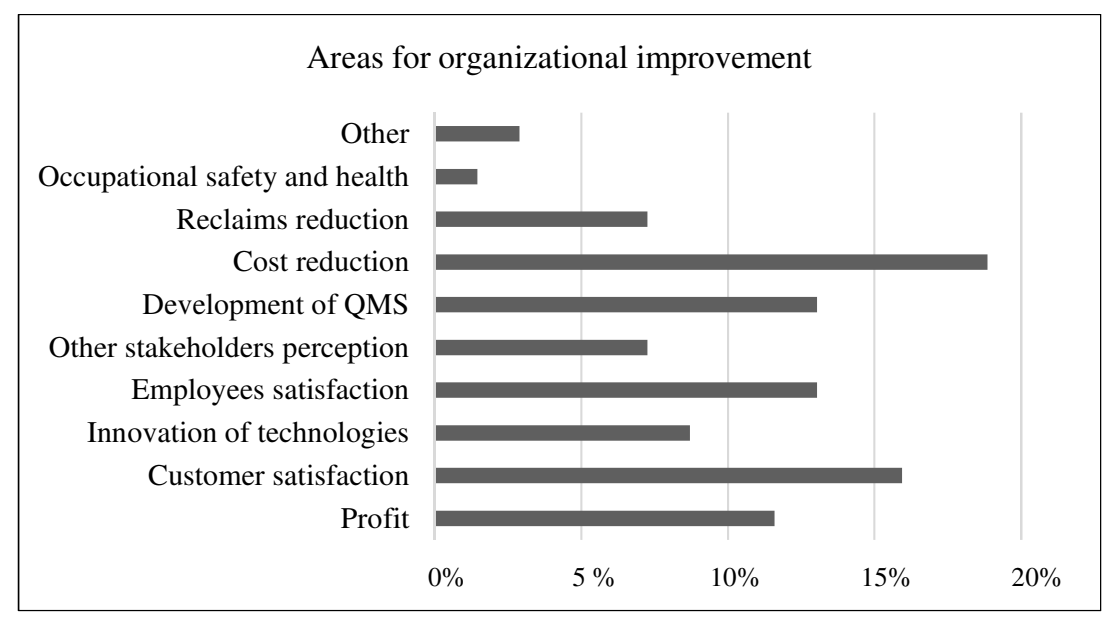

Figure 5 - The Most Important Areas for Improvement of Czech Organisations

\section{EXCELLENCE FRAMEWORK}

Such aspects as lack of information, insufficient knowledge, managers' mistrust, etc. are coupled with low level of people awareness in the area of the organisational excellence. Many people at Czech organisations simply do not understand the fundamentals, principles and meaning of this way to long-term success. We are sure an overcoming this obstacle through patient explanation and permanent discussion with all levels of employees is a crucial factor of more intensive work with excellence concept at Czech environment! Such communication needs an appropriate supporting tool. That is why a simple excellence framework tailored to the Czech environment and culture was designed. It is outlined by way of the scheme in Fig. 6.

A logic linkage that follows from this picture is not difficult to understand: if we want to assure the long-term success of any organisation, the best way is to adopt an organisational excellence concept. A common effect of this concept is a significant improvement of all organisations' results (financial and non-financial too). Better results are caused by the serious improvement of all stakeholders' perception, especially through external customers loyalty increasing. However, such perception changes must be considered as effects of necessary preconditions focused on permanent and agile improvement and innovations related to all aspects of advanced management systems. Management style, real value delivered to stakeholders, employees' knowledge development, individual processes capability and performance, or optimisation of material, information and natural resources consumption create the most significant aspects of improvement and innovation at present. 


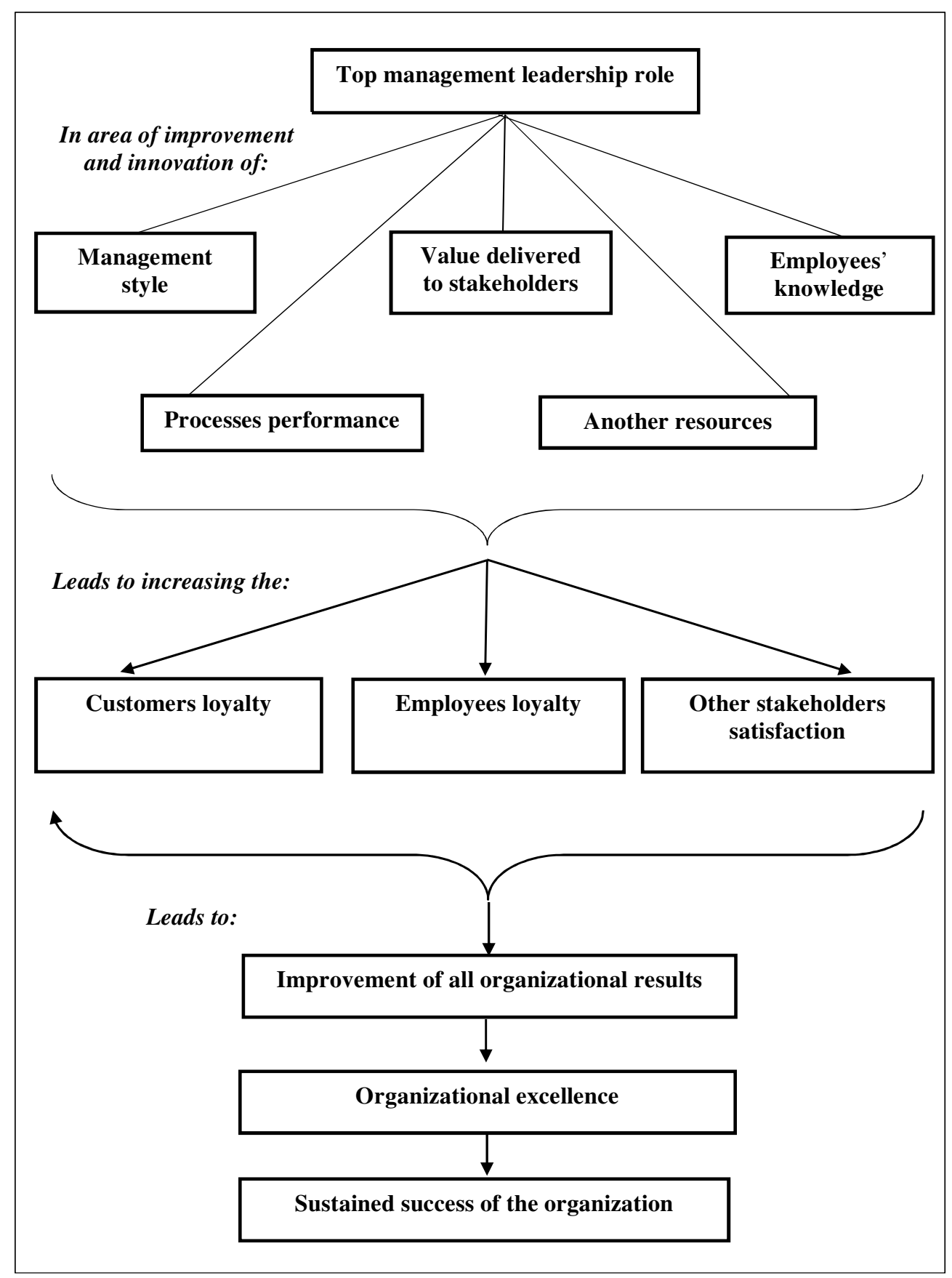

Figure 6 - Excellence Framework for Czech Organisations

Naturally, despite this scheme seems to be very simple, practical implementation can be a questionable effort. A lot of various problems and difficulties can occur. Just a quick troll through the problems linked to customer loyalty measurement at Czech companies is enough to illustrate one subjective limitation (Vykydal, 
Halfarová and Nenadál, 2013). Nenadál has already analysed some additional problems of excellence models implementation (Nenadál, 2016).

\section{CONCLUSIONS}

Organizational Excellence provides a competitive advantage - it is what makes one organization different from all of the other organizations in certain marketplace that provide similar products or services. Continuous commitment to the organizational excellence provides the tools to aggressively enhance your product or service, which in turn will assist you in building loyal customer relationships. Our investigation occurred that most of Czech organizations (including production companies) are not aware of this reality. Therefore, some final remarks concerning possible implications are directed to very them:

a) Journey to excellence is not only "the latest fad" or short-term campaign with risky effects. Working towards excellence means essential reducing costs through individual processes performance increasing and ability to deliver excellent value for any stakeholder;

b) development of advanced quality management strongly supports this journey (Goetsch and Davis, 2015);

c) various excellence models are widely applied not only at production companies, but also at other branches of business, healthcare (Markulik and Nagyová, 2012), education institutionsor other service area (Gouthier, Giese and Bartl, 2012) or (Zgodavova and Colesca, 2007);

d) this lead to improving shareholder's returns (Bolboli and Reiche, 2013), caused by improving all key financial indicators as return to equity, assets and capital, etc. (Dahlgard and Dahlgard, 2013);

e) unfortunately, these impacts cannot be exactly confirmed in the Czech environment due to the insufficient number of organizations engaged in excellence models' implementation;

f) the most of criteria included in excellence models can be difficult to understand by organization's staff and clear, deep and permanent communication or learning seems to be the only possible way how to overcome this barrier;

g) when adopting certain excellence model, all internal and external aspects (an organization's context) and rapidly changing business environment should be under consideration. In case we ignore such changes, huge effort should fail completely;

h) lack of money is not decisive limitation for the most of Czech companies when discussing barriers of journey to the organizational excellence. On the contrary: lack of knowledge was discovered and proved as crucial weakness. Knowledge management (focused on tacit knowledge first of 
all) should be considered as necessary precondition for all Czech organizations;

i) all findings presented at this article should come into support of the assumption that concept of the organizational excellence promoted by all excellence models can lead to important increasing not only quality of management but also to better quality of life!

Briefly to say: organisational excellence cannot be considered as overcomplicated matter, not even approach which is not suitable for Czech companies. It must be seen as an excellent opportunity for long-term business success! To successfully implement some excellence model, it does not matter of lack of money, not even lack of hardware. It is a matter of people engagement, education, training and motivation!

\section{ACKNOWLEDGEMENTS}

This paper was elaborated in the frame of the specific research project No. SP 2018/97 which has been solved at the Faculty of Metallurgy and Materials Engineering, the VŠB-Technical University of Ostrava with the support of Ministry of Education, Youth and Sports, Czech Republic.

\section{REFERENCES}

Al-Dhaafri, H., Al-Swidi, A.K. and Al-Ansi, A.A., 2016. Organizational Excellence as the Driver for Organizational Performance: A Study on Dubai Police. International Journal of Business and Management, [e-journal] 11(2), pp.47-52. http://dx.doi.org/10.5539/ijbm.v11n2p47.

ASQ, 2015. What is Organizational Excellence?. [online] Available at: $<$ http://asq.org/learn-about-quality/organizational-excellence/> [Accessed 24 November 2017].

ASQ, 2017. Malcolm Baldrige National Quality Award. [online] Available at: $<$ http://asq.org/learn-about-quality/malcolm-baldrige-

award/overview/overview.html> [Accessed 5 May 2017].

Bailey, D.M., 2014. Journey to Excellence. Quality Progress. 2014(August), pp.42-45.

Bolboli, S.A. and Reiche, M., 2013. A model for sustainable business excellence implementation and the roadmap. The TQM Journal, [e-journal] 25(4), pp.331346. https://doi.org/10.1108/17542731311314845.

Dahlgard, J.J. and Dahlgard, S., 2013. Business excellence models: limitations, reflections and further development. Total Quality Management and Business Excellence, [e-journal] 24(5-6), https://doi.org/10.1080/14783363.2012.756745.

pp.519-538. 
Duffy, G., 2016. Achieve higher levels of excellence through the capability maturity model. Quality Progress, June, pp.38-44.

EFQM, 2012. EFQM Excellence Model 2013. Brussels: EFQM Representative Office.

Eraclitus, 2005. Organizational Excellence Strategies and Improved Financial Performance. [pdf] Treviso: CQE University of Leicester. Available at: $<$ www.eraclitus.net/download/3-BQF2005.pdf> [Accessed 15 June 2017].

Fonseca, L.M.C., 2015. Relationship Between ISO 9001 Certification Maturity and EFQM Business Excellence Model Results. Quality Innovation Prosperity, [e-journal] 19(1), pp.85-102. http://dx.doi.org/10.12776/qip.v19i1.556.

Goetsch, D. and Davis, S., 2015. Quality Management for Organizational Excellence: Introduction to Total Quality. Harlow: Pearson Higher Ed.

Gouthier, M., Giese, A. and Bartl, Ch., 2012. Service Excellence models: a critical discussion and comparison. Managing Service Quality: An International Journal, [e-journal] 22(5), pp.447-464. http://dx.doi.org/10.1108/09604521211281378.

GWU, 2017. The Comparison of the Deming Prize and Baldrige Award. [online] Available at: <www2.gwu.edu>. [Accessed 22 May 2017].

Hoskote, P., 2015. Organizational Excellence framework - How to fail. [pdf] OES. Available at: <http://organizationalexcellencespecialists.ca/wpcontent/uploads/2015/10/Organizational-Excellence-Models-How-to-Fail-PH10.06.2015.pdf $>$ [Accessed 9 May 2018].

ICMA, 2016. In Search of orgnizational Excellence?. [online] Available at: $<$ https://icma.org/articles/pm-magazine/pm-article-search-organizationalexcellence?> [Accessed 23 October 2017].

ISO 9004, 2018. Quality management - Quality of an organization - Guidance to achieve sustained success. Geneve: ISO.

JUSE, 2017. On revision of Deming Evaluation Criteria. [pdf] JUSE. Available at: $\quad<$ https://www.juse.or.jp/upload/files/On_revision_of_Deming_ Evaluation_Criteria_From_FY_2018_Second\%20Announcement.pdf $>$ [Accessed 11 April 2017].

Kanji, K.G., 2015. Measuring Business Excellence. New York: Routledge.

Kiitam, A. and Tammaru, T., 2012. Impact of application of excellence models on organizational performance. In: Tallinn University of Technology, $8^{\text {th }}$ International DAAAM Baltic Conference, "Industrial Engineering". Tallinn, Estonia, 19-21 April 2012. Tallinn: Tallinn University of Technology.

Ladzani, W., 2016. Benchmarking the South African Excellence Model against worldclass best practice business Excellence Models. Environmental Economics, [e-journal] 7(4), pp.8-19. http://dx.doi.org/ 10.21511/ee.07(4).2016.01. 
Mann, R.S., 2011. Impact of Business Excellence/Quality Awards on Enterprises. Tokyo: Asian Productivity Oganization.

Markulik, S. and Nagyová, A., 2012. The proposal of QMS implementation in healthcare office. Journal of US-China Medical Science, 9(3), pp.68-71.

Musa, P., Tulay, G., 2008. Investigating the Impact of Organizational Excellence and Leadership on Achieving Business Performance: An Exploratory Study of Turkish Firms. SAM Advanced Management Journal, 73(1), pp. 29-45.

Nenadál, J., 2016. Systémy management kvality. Co, proč a jak měřit? Praha: Management Press.

Oakland, J.S., 2014. Total Quality Management and Operational Excellence. Text with Cases. 4th Ed. London: Routledge.

Shirvani, A. and Iranban, S., 2013. Organizational Excellence Performance and Human Force Productivity Promotion: A Case Study in South Zagros Oil and Gas Production Company, Iran. European Online Journal of Natural and Social Sciences, 2(3), pp.3010-3015.

Vykydal, D., Halfarová, P. and Nenadál, J., 2013. Customer Loyalty Measurement at Czech Organizations. Quality Innovation Prosperity, [e-journal] 17(1), pp.28-38. http://dx.doi.org/10.12776/qip.v17i1.66.

Webster, M., 2016 Organisational Excellence. So what is organizational excellence, [blog] 25 August. Available at: $<$ https://realorganisationalexcellence.com/2011/08/25/so-what-is-organisationalexcellence/> [Accessed 12 December 2017].

Zgodavova, K. and Colesca, S.E., 2007. Quality Management Principles - An Approach in Healthcare Institutions. Management \& Marketing, 5(1), pp.31-38.

Zgodavova, K., Hudec, O. and Palfy, P., 2017. Culture of quality: insight into foreign organisations in Slovakia. Total Quality Management \& Business Excellence, [e-journal] 28(9-10), pp.1054-1075. http://dx.doi.org/10.1080/14783363.2017.1309120.

\section{ABOUT AUTHORS}

Prof. Ing. Jaroslav Nenadál, Ph.D. - VŠB-Technical University of Ostrava, Faculty of Metallurgy and Materials Engineering, Department of Quality Management, 17. listopadu, Ostrava-Poruba 708 33, Czech Republic, e-mail: jaroslav.nenadal@vsb.cz.

Ing. David Vykydal, Ph.D. - VŠB-Technical University of Ostrava, Faculty of Metallurgy and Materials Engineering, Department of Quality Management, 17. listopadu, Ostrava-Poruba 708 33, Czech Republic, e-mail: david.vykydal@vsb.cz. 
Ing. David Waloszek - process quality engineer, Brose CZ Kopřivnice, e-mail: david.waloszek@brose.com.

(C) 2018 by the authors. Submitted for possible open access publication under the terms and conditions of the Creative Commons Attribution (CC-BY) license (http://creativecommons.org/licenses/by/4.0/). 